\title{
Digu Puja : A ritual to revitalize the family unity among the Newars
}

\section{Tina Manandhar}

\begin{abstract}
Digu puja is a ritual of worshipping lineage god among the Newars of Kathmandu valley. With the brief discussion of the puja rituals this paper gives a detailed account of the family system in Nepal starting from ancient period. Following the developments in the field of education and politics how the joint family system was disintegrated and how the concept of nuclear family emerged in Nepal will also be discussed. And finally, how other festivals along with Digu Puja are helping to create a binding link amongst the separated family members will be analyzed.
\end{abstract}

Key words: Nepali family system, lineage God, Digu Puja, Newars' family unity.

\section{Introduction}

Religion and culture have a significant role in the Nepali society, especially among the Newars, the dominant ethnic community of the Kathmandu valley. The Newars do not have a single caste but have a group of castes who have their similar language and culture. This group is composed of Hindu and Buddhist faiths (Gellner,1994:52). Religion is highly significant in the Newar society. Apart from the festivals that are observed within the small limit of a single family, people also observe festivals requiring participation of families of different generations from a single lineage. These festivals help them to create unity amongst the family members who by some reason are not staying together in a large joint family. 'Digu Puja' is one such occasion which is celebrated in a joint manner by all the family members of different generations of the same lineage. The concept to worship the lineage god is also found among the Non-Newars, and they call it 'Dewali' Puja'. But the way they celebrate it is different from the Newars. Unlike the Newars, they celebrate their 'dewali puja' once in three, five or twelve years, whereas the Newars observe it every year, and in some castes even two or three times a year. In addition, the Newars celebrate the 'puja' as a religious and cultural festival. Ways of celebration may be different but the concept is similar, which is - to bring all the family members in one place and create the feeling of oneness. During 
the 'puja', a concept of seniority order is strictly maintained. Youngsters always respect the elders and follow the rules set by the seniors. As such, this kind of celebration also teaches the lesson of honouring senior family members. Not only 'digu puja' but all the festivals that are celebrated in one or another way teach the value of respecting the elders and creating strong family bonds.

\section{Nepali Family in Historical Perspective}

Family is a group consisting of persons who are related to each other by ties of blood, marriage, or adoption. It is the family that provides emotional and psychological security to its members and supports those who are young, old or physically unable to earn money. Moreover, family is the first and basic step where everyone is groomed to become a perfect citizen, who can contribute to the society and country. It is the first institution where everyone gets proper training to make their identity. In every society people are attached to their family from birth to death. Family plays a vital role in their progress and prosperity. So it would be fair enough to say that family is the focal point for the welfare of any society and the country as well. People can perform their duties well if they are supported and encouraged by their family. That is why people in ancient times used to live in joint families, helping and supporting each other. Especially the Hindu mythological texts describe it as one of the prime duty of the people to live in a joint family. Nepal, now a secular state, used to be the only Hindu Kingdom until recent past. The concept of living together in joint families as described by the Hindu texts was followed in Nepal from time immemorial. The Newars, who are composed of Hindu and Buddhist faiths, strictly adopted this tradition according to the Hindu texts, at least up to mid-twentieth century.

Joint family system was prevalent in Nepal during ancient and medieval period. During those days, people paid great respect to the Hindu texts, and preferred to live in joint family system as mentioned in different literary and epigraphic sources. It may also be influenced by the agrarian nature of society which was prevalent in the country and which demands the active participation of all the family members in agricultural activities. In most of these inscriptions, the king used to address only the chief of the village and family to communicate the order of the government. During the medieval period, a census would be taken according to the number of household and not of an individual family member (Vaidya, Manandhar and Joshi, 1993:53). More than this, if any member of the family committed any crime, the whole family members were liable to punishment, except in some rare cases where special order was given by the king to punish the culprit only. In most of the cases, whole family members were punished so as to show that in a single joint family, every member was responsible for a crime( Vaidya and Manandhar, 1985:25). Such kind of practice was also followed in China and India during ancient times (Vaidya, Manandhar and Joshi, 1993:50). The unity among the members was very strong in a joint family during medieval Nepal. The crafts and sculptures made during that period testify this point. Especially the sculptures 
of Lord Shiva and Parvati made during that period are shown along with their two sons, Ganesh and Kumar, while the similar kind of sculptures made during the Licchavi period have images of only Lord Shiva and Parvati. Even though all these gods are famous and worshipped for different reasons, crafting them as a single family gives an example of an ideal family.

The practice of taking census according to the household and not of an individual person continued during the medieval period also. It is also said that even the states were referred by the total number of households of that state, like twelve thousand for Bhaktapur, and twelve thousand for Gorkha. Popular saying that no one can make his separate single family until the parents are alive, strongly suggests the importance of joint family during those days. Another reason for living together in a large joint family was the question of security. Because of the turbulent situation, people were forced to live in a large group within the territorial limits. Family members of three to four generations used to stay together in a large joint family. The senior most member was the head of the family and was respected by all. He used to supervise family activities as a guardian and his instructions were strictly obeyed by the family members, even if any family member started to live separately because of some unavoidable reason.

After the unification of Nepal during the second half of the $18^{\text {th }}$ century, there was a slight change in the concept of a joint family. One possible reason for this was the end of minor warfare which was frequent during medieval period when the country was divided into many small principalities. With the unification of these principalities into one single state, the people were assured of security and they began a new practice of living in a separate small family, mainly consisting of couple and their children. Another reason of departure from joint family system was migration. As the capital of the country was transferred from Gorkha to Kathmandu, lots of people migrated to Kathmandu. Those who migrated at that time were mainly the high class government officials who came along with their families. Migration from the Kathmandu valley also took place because of the stationing of government officials to different districts. Under such a situation, the concept of single family developed at least among the government officials. Even then, those separated family members usually visited their joint family during the time of lineage god worship or other major family activities. Whatever may be the reason, the system of living in large joint family was slightly changed, and the concept of small nuclear family emerged. Although people started to live in nuclear families, the provision of punishing the whole family along with the culprit remained somewhat same during the early Shah period also. There are few examples of such kind of punishments. For the mistake of few Jaisi Brahmins, all Jaisi Brahmins were deprived of their priestly job during the reign of King Prithvi Narayan Shah (1742-75) (Vaidya and Manandhar, 1985:124). Provision of serious punishment was made for the whole family if any one in the family was involved in bribery cases. These types of 
punishment were more severe during the reign of King Rana Bahadur Shah (1778-99). Upon the grave misuse of the religious property, the main culprit would be given life imprisonment whereas his family members were made slaves(Nepali, 1988:123-130). Whatever negative impression these kinds of punishments may give, one moral guideline was established that the character of an individual was attached to his family for any good or bad deeds. These types of punishment for the whole family even for the mistake of a single member suggested that the trend of living in joint families continued during the early Shah period.

During the Rana period (1846-1951), the practice of living in nuclear families increased. It was mainly because of the influence of the West. Specially the high class Ranas were much impressed by the Western lifestyle, and they started adopting it. Grown-up sons were placed in different palaces as they thought these kinds of distances would increase more intimacy. Common people were unable to copy the same lifestyle because of their poor economic condition. Even though the Ranas practised to start living in separate families, the civil code made during the Rana period still favoured the joint family system(HMG, 1965:112). Not only it stressed the importance of living together but also fixed some punishments if a son tried to live separately without the consent of his father(HMG, 1965:112 ). These kinds of legal arrangements show that the joint family system was prevalent even during the Rana period. It was only the high class people who tried to live in separate nuclear families.

Hence, in Nepal the joint family system has been favoured since the ancient period and people were attached to large joint families, at least legally. Although because of various reasons people lived in nuclear families, they were legally bound with seven generations of the family for social obligations. Marriage within those generations was not legally accepted. In the case of inheritance of property of a childless couple, it would be claimed by the relatives unto seven generations.

\section{Disintegration of the Family System}

There are several reasons for the disintegration of joint family system in Nepal. Family dispute is the determining factor in dividing a joint family into many nuclear families. Family dispute may arise due to many causes. Polygamy, unequal status of different members, and conflicting ideas among family members are some of the reasons that create trouble in the joint family resulting in the break up of joint family. Influence of Western lifestyle, educational activities and search for better job opportunities may also compel them to live in separate families.

From the ancient period, Nepali family had been patriarchal. Though there were few examples of matriarchal families in some communities of remote areas, in general, the senior most male family member used to be the head of the family. Family life was 
much influenced by the Hindu 'dharma shastras'. These texts stress that the continuity of a family is possible only by having a son and a couple without son would not find any place in heaven. This concept that a son would place the ancestors in heaven creates a strong feeling to have a son especially among the male members of the family. For the sole purpose of having a son, he would not even hesitate to marry more than one wife. Later on, in a male-dominated society, marrying more than one wife was associated with the prestige of a man. Such practice of polygamy would create disputes in dealing with the family property regarding beneficiaries and inheritors. Not only among the common people, even in the royal family, the interference of different queens of a ruling king resulted in political turmoil in the country. Polygamy always brought family conflict over the ancestral property which generally resulted in the breakdown of a family. According to law, every member had the equal right to the ancestral property, but there was a difference between the legitimate child and the illegitimate one. The former would get the ancestral property six times more than the latter (Vaidya, Manandhar and Joshi, 1993:55). The controversy over the legitimate and illegitimate issues was at its apex when the Rana family was classified into different classes and the one belonging to lower class was not even permitted to enter and worship their lineage god (Vaidya, Manandhar and Joshi, 1993:57). Barriers were made even in dressing and food provisions. Such kind of social humiliation forced the lower class Ranas to revolt against such system of joint family (Joshi and Rose, 1966:75). In the case of common people also, there were lots of dispute over the division of ancestral property which created fractions amongst brothers, resulting in the disintegration of the joint family system, as everyone felt the necessity of a nuclear family to get rid of the family dispute

Unequal status of family members was another reason of family feud. It may be seen in the form of unequal earning by different members of the family, and also in the form of favour shown by the parents to some specific member, the ultimate result of which was the break down of the joint family system. Conflicting ideas on different issues among the family members may also create trouble in the joint family. This type of problem is seen especially in the well educated families.

Influence of Western society was another reason for the disintegration of a joint family. At a time when Nepal was slowly emerging as one of the developing nations, the Western society was taken as a model which is based on the principles of equal opportunity and right to both men and women. Particularly the educated people believed that the Western society could develop because of the single family system. In their opinion, such practice would not affect love and affection among the family members, and would rather increase it. At the same time, it would help the younger generations to be independent and labourious to sustain themselves. The high class people of Nepal were very much influenced by this idea. In addition, some people considered the adaptation of the lifestyle of Westerners as a matter of pride. To some extent, the concept to make the young kids independent was reasonable but 
with the creation of single family system the attachment among the family members became so formal that they treated their own family members as alien. Love and affection among them was virtually lost. With the rise of democracy in Nepal in 1951, there was a tremendous development in education and it was considered a must for the overall development of the country. Formerly, the females were given little opportunity in education, but now they came forward in this field. The female education taught them the idea of being independent of the male members and it also contributed to the formation of single families. Apart from that, everyone felt the necessity to provide good education to his children, and for this the children at least among the high class families were sent from village to city and from city to abroad for quality education. The quest for good education unknowingly created frictions amongst the family members and in turn affected the family system as well. After being well educated, it was obvious to seek and get better jobs. This search for better jobs also led people to leave their homes which indirectly helped to create new single families.

\section{Rituals to Unite the Family System}

Besides "digu puja", the Newars celebrate other religious festivals and rituals as well in which all the family members participate. These festivals and rituals help them to strengthen the family ties. These festivals also play a major role in making close contacts between the married daughters with their parental home. Among these festivals, the first and foremost is 'Dashain'. Celebrated both by Newars and non-Newars, this festival plays a major role in uniting all the family members who are staying separate. Among the Newars, the rituals of this festival are observed by the family head in his own house, but all of them gather in the house of the senior family member for the formal celebration. All the family members gather together in the house of the senior member of the family up to three or four generations and participate in the feast and 'puja' rituals. The festival is concluded by receiving ' $t i k a$ ' (auspicious red mark on forehead) from the senior member of the family. In this regard, married daughters also receive ' $t i k a$ ' in their father's house. If a married daughter is not asked to receive ' $t i k a$ ', it is considered to be most humiliating, and some times may lead to her exclusion from their paternal house. Some times, the death of any family member of three or four generation affects the 'puja' rituals because of the mourning period. In such a case, rituals are observed after the certain days of death pollution and the rituals are carried out in a most simple way. Staying together with the family members throughout the festival increases the intimacy among the family members. The trend of receiving 'tika' from the elder family member builds the feeling of respect among the younger generation towards the seniors.

Another major religious festival celebrated after 'Dashain' is 'Tihar'. Though celebrated for five days, the last day is of great importance to all the brothers and sisters. This day is known as 'Bhai Tika' or Brother's day. The day is celebrated by the sisters offering and praying for the long, healthy and prosperous life for their brothers. The married 
daughters invite their brothers to their husband's house for the celebration. This ritual builds the feeling of unity among the brothers and sisters. In the lack of a brother from the same father and mother, the sister prefers the son of her uncle for the 'bhai tika'. The brother or sister living far away visits his/her house for this celebration.

To mark the respect to the parents, the Newars celebrate Father's and Mother's day once a year. Sweets and gifts are offered by the children to their parents to show their affection and love towards them. Even the people, whose parents have already died, go to the religious shrines and offer their homage to the deceased parents by giving 'dan' (offerings) to the Brahmin. It is believed that the deceased parents would get the offerings in the heaven. These days (Father's day and Mother's day) are of great importance to the married daughters. In the past, when there was no facility of easy transportation, married daughters took this day as one when they could meet their parents.

'Sraddha' is another ritual which is observed to mark the death anniversary of the late ancestors. In the Newar society, an elder son takes responsibilities of his father while the younger son takes the responsibilities of his mother. This trend continues even after the death of the parents. The death ritual of the father is done by the elder son and that of mother by the youngest one. But no matter whoever performs the death rituals or 'Sraddha', the participation of the whole family in the occasion is obligatory. When the 'sraddha' of the ancestor in the lineage is performed during 'digu puja', all the families belonging to the same lineage attend the function.

All these examples of the participation of family members in any religious festival or rituals prove that despite of staying in nuclear families, these kinds of rituals help to maintain cooperation and harmony among the family members.

\section{'Digu puja'}

From the above discussion, we can say that the religious festivals and rituals plays a significant role in keeping the joint family system alive. Among these festivals, 'digu puja' is a special occasion which is helping to create a feeling of belongingness of a large joint family to a maximum extent. 'Digu Puja' is a ritual observed by the families of a single ancestor of four or five generations' which are living as separate families. All the members worship the lineage god together followed by the feast, and this celebration lasts for four or five days. Although celebrated for a short time, this ritual helps to re-establish the feeling of oneness among the separated members of the large joint family at least for certain days.

The concept of worshipping the lineage god can be dated back to ancient times. Even in the epics of the Ramayan and the Mahabharat, a lineage god is mentioned, The Sun is considered to be the lineage god of Ram, and the Moon that of Krishna in the Mahabharat (Manandhar,2014:40). Same tradition of worshipping the lineage god can be seen among the 
Newars. As already discussed, because of various reasons, the popularity of nuclear families have made people to settle with their small family of husband, wife and their offsprings. In such a situation, the celebration of 'Digu Puja' re-establishes the union of persons belonging to the joint family of four or five generations. Throughout the 'puja' ceremony, everyone goes through the strict rules set by the seniors. To carry out all the rituals smoothly, the Newars follow the system of 'Guthi', which has been preserved and continued for hundreds of years. 'Guthi' is a system which is established for a certain task which might be either social work or related to culture as to celebrate any festival or ritual work or to accomplish rituals related to a man especially at the time of death(Toffin). When such 'guthis' are established, a source of income for its smooth run is also provided. For this purpose, some land, building, property, etc are established in the name of the 'Guthi'. The responsibility to run this 'Guthi' and use its property properly is upon its members (Manandhar, 2014:67). For the celebration of the 'Digu Puja', they have 'Digu Puja Guthi'. The main function of this 'Guthi' is to make arrangements for the puja of the lineage god and feast related to it. The members of this 'Guthi' are the members of the joint family from the same patrilineal side. They are called 'Phuki'. Membership is hereditary. But in the case of a female, she loses it after her marriage by joining the spouse's 'Guthi'. (Manandhar, 2014:74)

Cooperation from all the family members to celebrate the ceremony is one of the important features of this digu puja ritual. Each year, one family gets its turn to organise and look after the necessary arrangements. This responsibility is rotated every year amongst families. Although the duty to arrange the necessary items of both 'puja' and feast is given to one family each year, the role played by other families cannot be ignored. After the ' $p u j a$ ', delicious food items are prepared for the feast with the help of all the family members.. 'Nau' or 'Nai' performs the purifying process a day before by cutting the toe nails. 'Kusle' or 'Jugi' plays traditional flute on the way to the lineage god's shrine and on the way back. Even though help is taken from other Newar communities, the participation of other caste in the main ' $p u j a$ ' is strictly prohibited.

Another noteworthy feature of this puja ritual is the strict rules and regulations. The rules set by the elders are strictly followed throughout the duration of ' $\mathrm{p} u j a$ '. Participation of all the members is mandatory, the failure of which is punished with fine. Especially during the 'Swan Chayegu' (offering of flowers), presence of all the family members is a must. The head of the lineage performs all the 'puja' ceremony under the instruction of the priest with help of other family members. It is done with the conviction that the head of the lineage represents the entire family before the lineage god and it is through him that the lineage god passes his blessings to the entire family. Hence, the head of the lineage is respected so much that all through the 'puja', his instructions are considered to be final. 


\section{Conclusion}

With the rapid change in every field of life in this modern age, people become more concerned about their career. Better career and good job options make people to leave their home and start living in a nuclear family of husband, wife and their offspring. This practice has created an unwanted distance among the family members, as they get less time to interact with each other. In such a situation, digu puja has become a binding link amongst the family members at least once or twice a year. This ritual in this modern age is helping to create unity amongst the family members. Young kids are taught to respect the seniors and follow their tradition.

However, this ritual needs some modifications if the coming generation is to accept this culture earnestly. First, the five-day long duration is firmly opposed by the younger generation who find it difficult to engage themselves for such a long period. Secondly, the animal sacrifice has come under heavy criticism, and a loud voice is raised against it. Thirdly, voices are also being raised to simplify the puja rituals to perform the occasion in an easier way. And lastly, the younger generation is demanding the restoration of the 'Guthi' 'lands of the concerned families which have been confiscated by the government in the 1960s in the name of land reform.

At present, the first three modifications are being applied by most of the families, but as for the 'Guthi' land, the Newar community should be united as a pressure group to take back their confiscated lands from the government.

\section{References}

Anderson, M. (1975). The festivals of Nepal. New Delhi: Rupa and Co.

Gellner, D. and D Quigley. (Eds.) (1995). Contested hierarchies. Oxford: Clarendon Press.

Gellner, D. (1992). Monk, householder and tantric priest, Cambridge: University Press

Joshi, B L \& Rose L E. (1966). Democratic innovations in Nepal. Berkeley: University of California Press

Khatri, P \& Dahal P. (1996). Social history of modern Nepal. Kathmandu: Sajha publications, (in Nepali).

Manandhar, J.B. (2004). Collections of essays on Manandhar. Kathmandu: Tara Devi Manandhar (in Newari).

Manandhar, T. (2014). Digu Puja : Lineage god worship (A cultural study of the Kathmandu city). Unpublished doctoral dissertation. Tribhuvan University. Kathmandu, Nepal.

Muluki Ain. (1965). Kathmandu: His Majesty's Government Nepal, Ministry of Law and Justice. 
Nepali, G. S. (1988). The Newars. Kathmandu: Himalayan Book Sellers,

Sharma, P.R. (1997). Lineage, land and state. Kathmandu: Centre for Nepal and Asian Studies, (in Nepali).

Surav, S. (1976) "Dewali : Ek parichaya" (Dewali: An introduction). Our Culture. Kathmandu: Sajha Publication, ( in Nepali).

Toffin, G. (2007). Newar society. Lalitpur: Himal Books.

Vaidya, T.R \& Manandhar T R. (1985). Crime and punishment in Nepal: A historical perspective. Kathmandu: Bini Vaidya and Purna Devi Manandhar

Vaidya, T .R., Manandhar T R and Joshi S L. (1993). Social history of Nepal. Delhi: Anmol Publications. 